\title{
Early Versus Late Start in Foreign Language Education: Documenting Achievements
}

\author{
Rocío Domínguez \\ GTZ \\ Silvia Pessoa \\ Carnegie Mellon University
}

\begin{abstract}
This study compares 27 sixth grade students who have been learning Spanish since kindergarten with 5 who have had Spanish for only 1 year using a battery of Spanish oral and written tests. The students who started early outperformed the new students in listening, speaking, and writing Spanish. Those who started early also displayed a positive attitude toward speaking Spanish in the classroom, a high level of confidence in their Spanish oral and literacy skills, and the use of sophisticated language structures in writing. These findings provide additional evidence supporting the case for early foreign language learning.
\end{abstract}

Key words: content-based instruction, early versus late second language learning, foreign language in the elementary schools (FLES)

Language: Spanish

\section{Early Versus Late Foreign Language Education: Why Start Early?}

Even though Krashen, Long, and Scarcella (1979) concluded that early foreign language learners show better results than older ones in the long run, later studies of the early-late distinction have provided conflicting findings. In many cases, these studies focused on a particular skill or task (e.g., reading comprehension), thus making it difficult to conclude anything substantial about an early start. The present study presents findings that support foreign language learning for early learners based on results from a battery of oral and written tests comparing the academic and nonacademic language skills of two groups of children. In addition, this study includes students' perceptions of their language learning skills.

Singleton (2001) provided a recent review of research on the impact of age on second language acquisition (SLA) and discussed various trends in this area. Harley (1986) concluded that an early start may lead to greater oral proficiency and confidence in using the target language. Furthermore, Harley and Wang (1997) found that early learners outperformed older ones not only in pronunciation, but also in morphology and syntax. Regarding the achievements of late beginners, studies show that some learners whose exposure to a second language (L2) begins after age 12 can nevertheless acquire nativelike pronunciation (Bongaerts, Mennen, \& Van der Slik, 2000; Bongaerts, van Summeren, Planken, \& Schils, 1997; Palmen, Bongaerts, \& Schils, 1997). These studies are consistent with the results of Scovel (1988) and Flege (1999), who found that children can attain nativelike pronunciation in their L2.

Rocío Dominguez (PhD, Carnegie Mellon University) is a consultant for the Deutsche Gesellschaft für Technische Zusammerarbeit (GTZ), Lima, Perú.

Silvia Pessoa (PhD candidate, Carnegie Mellon University) is a graduate student in second language acquisition at Carnegie Mellon University, Pittsburgh, PA. 
Researchers have begun to identify other factors that are intrinsically related to age of learning and that may affect SLA. For example, DeKeyser (2000) found that the few adult beginners in his study whose scores were identical to those of child beginners had high levels of verbal analytical ability. According to DeKeyser, these results suggest that maturational constraints apply only to implicit language learning mechanisms.

Harley and Hart (1997) indicated that differences of instructional styles associated with primary and secondarylevel education may be a factor related to L2 age of learning and ultimate proficiency. Another factor under investigation is motivation (Marinova-Todd, Marshall, \& Snow, 2000). Findings suggest that some older beginners who achieve nativelike proficiency have very high levels of motivation (Ioup, Boustagui, Tigi, \& Moselle, 1994; Moyer, 1999). Given these mixed results, it is clearly important to continue investigating the language learning of students who begin earlier or later in Foreign Language in the Elementary School (FLES) programs.

Some studies comparing young foreign language learners to older ones show great inconsistencies in their design and are based on programs where students are taught the target language in brief daily lessons. For example, Bennett (1975) argued that the massive British study (Burstall, Jamieson, Cohen, \& Hargreaves, 1974) conducted during the 1970s that investigated the advantages of introducing instruction in French as a foreign language at age 8 did not consider parental occupation or socioeconomic status as an important variable for L2 learning. According to this study, the only positive effects of an early start were high performance on a French listening test and more confidence in speaking French. The students who began earlier did not, however, perform better on a speaking test. Stern (1976) identified another problem in the Burstall et al. study: Once children arrived in secondary school, early learners with L2 experience were often mixed in the same classes with those who had just started learning the target language. Stern concluded that because the young learners were not challenged, they did not take advantage of their prior L2 learning.

Harley (1998) reported similar problems in the study conducted by Oller and Nagato (1974). In this study, results showed that the Japanese 11th graders who had received English instruction since grade 1 performed no better on a written fill-in-the-blank test in English than those who had received instruction since grade 7 . As in the previous study, there was a lack of consistent placement between elementary and secondary school and, by grade 8 , early- and later-beginners were mixed in the same classes. In addition, the final test did not evaluate the students' listening and speaking performance, which had been the focus of the elementary program (and where advantages for an early start would have more likely been found). We may conclude that additional research is needed to investigate whether early learners perform better than older ones in oral skills.

In a survey of foreign language education in 19 nations, Pufahl, Rhodes, and Christian (2000) reported that respondents from around the world believe that early learning of a foreign language in elementary and preschool education promotes higher levels of language proficiency in multiple languages. For example, in Thailand, English is a compulsory subject beginning in first grade.

Evidence from studies of students in French immersion programs also favors the introduction of a foreign language at an early age. Results from these studies consistently indicate that immersion students performed as well as or better than their monolingual English-speaking peers on all standardized measures of achievement in mathematics, science, and social studies (Curtain \& Pesola, 1994; Lambert \& MacNamara, 1969; Lambert \& Tucker, 1972; Rafferty, 1986; Swain, 1984). Comparative studies between early and late immersion students who had reached the same age in secondary school have shown that late immersion students sometimes catch up with early immersion students in writing and in reading comprehension. As for oral skills, early immersion students typically retain an advantage on communicative tests of listening comprehension and speaking when compared with late immersion students. Compared with late immersion students, those who start early express greater confidence in using all four skills. These results reaffirm the conclusion that early foreign language learners benefit more in oral communication than those who start their foreign language instruction late (Genesee, 1987; Swain \& Lapkin, 1986; Wesche, Morrison, Ready, \& Pawley, 1990). Furthermore, research on early L2 learning has provided evidence of cognitive, academic, and attitudinal advantages for children who start foreign language instruction early (Cummins 1981; Cummins \& Swain, 1986; Lapkin, Swain, \& Shapson, 1990; Swain \& Lapkin, 1986).

Although the research findings are inconclusive, there seem to be numerous advantages to beginning foreign language study at an early age. Children who begin early appear to develop better L2 oral proficiency and to feel more secure in their oral L2 performance. Early learners may also have comparative advantages in relation to their monolingual peers with respect to cognitive development, academic achievement, and attitudes toward the target language and culture.

This study reports the results of a battery of Spanish oral and written tests administered to 32 sixth graders in a Spanish FLES Program. Twenty-seven students had been learning the target language since kindergarten, thus, for purposes of this article they are considered early learners. Five students had received only 1 year of Spanish instruction. Because of the small sample, the findings of the present study cannot be generalized, however, they are meaningful 
to the extent that they show the same tendencies as those of previous studies. It is our intent to address the following questions:

1. Do early learners outperform new students in their Spanish oral and literacy skills?

2. Is the gap between listening and speaking skills greater for new students than for early learners?

3. Is the gap between reading and writing skills greater for new students than for early learners?

4. Are early learners more confident of their Spanish oral and literacy skills than new students?

By providing answers to these questions, we want to contribute to the case for early foreign language learning.

\section{Study}

\section{Spanish Program in Grade Six}

This study was conducted in a suburban public school district in Pennsylvania. In 1996, with the initiative of the district superintendent, the school district began a Spanish FLES program (Tucker, Donato, \& Murday, 2001). At the time this study was conducted, Spanish was taught in grades $\mathrm{K}-6$.

In grades K-5, 20 minutes of the school day was dedicated to Spanish instruction. In grade 6, Spanish was allocated the same amount of time ( 40 minutes) as other "core" subjects such as reading, English, science, and social studies and there was a special focus on literacy. The two sixth grade instructors taught Spanish to 260 students, one of Hispanic background, distributed in 10 sections.

\section{Spanish Teachers in Grade Six}

The sixth grade Spanish teachers, Richard and Susan (pseudonyms), are both certified teachers with master's degrees in Spanish. At the time of the study, Richard had been teaching for 2 years and Susan had been teaching for 1 year.

\section{Sixth Grade Spanish Curriculum}

The Spanish FLES program is a content-based program, which supports the content curricula from four core courses: reading, English, social studies, and sciences. In addition, the curriculum was designed in accordance with the five goal areas of the Standards for Foreign Language Learning (National Standards, 1996): communication, culture, connections, comparisons, and communities. A wide variety of class activities were designed for students to develop their interpersonal, interpretive, and presentational skills in both oral and written Spanish. Students also had an opportunity to make connections and comparisons with other content knowledge of core courses, as the curriculum content is taught first in English, and then in Spanish.

\section{Data Collection}

\section{Participants}

At the start of the program in 1996, a pool of approximately 40 students (with an equal number of boys and girls) was randomly selected for continuous evaluation. At the end of each of the past 6 years, the Spanish teachers, assisted by members of the university partnership, have tested this same pool of students. Since the initial selection of this pool, some students have left the school, leaving $27 \mathrm{stu}-$ dents to be tested in May 2003. Of these students, 14 were girls and 13 were boys; 14 students came from Richard's sections and 13 from Susan's sections.

During the 2002-2003 school year, 10 new students had joined the Spanish program in grade 6. Of these 10 students, only 5 were tested due to a variety of reasons (e.g., late program start, special needs, absence). The sample of new students consisted of 3 boys and 2 girls. With the exception of one child who had Spanish when she was in first grade, none of the new students had learned any other language in their former schools. All of the students were native speakers of English, and all but two participated in the "repaso" (review) held 2 out of 6 days.

\section{Sources of Data Collection}

The five sets of data described below were compared and contrasted in order to provide a comprehensive picture of the students' proficiency and confidence in Spanish.

\section{Spanish Final Test (SFT)}

This test was taken in May 2003 and consisted of a listening task, two speaking tasks, a reading task and a writing task.

\section{Listening Task}

In this task, students were tested in their comprehension of eight discrete Spanish commands. The learner responded physically, not orally, and the tester was able to repeat the command to the examinee only twice. Each repetition of the command was counted as a prompt and the rater used a two-point scale to evaluate students' responses regarding the accuracy and the number of prompts needed. For each correct response, the learner earned two points; for each correct response requiring a prompt, the learner earned one point; and when students did not respond or answered incorrectly, they received no points.

\section{Speaking Tasks}

Students participated in two oral tasks. The first task required the child to answer questions about a picture orally in Spanish. The learner's responses were evaluated in terms of their understanding of the questions, regardless of grammatical errors or utterance length. Susan and Richard tested each other's students and used the same two-point rating scale described above. In the second oral task, the child described a set of pictures using as much detail as 
possible. The child had the opportunity to examine the pictures prior to the test, and was instructed to think of "all the things that they could say about the pictures in Spanish." Spanish oral prompts and questions given to the students were more open-ended than those in the first oral task. For example, the tester may have said "tell me about the people in the picture and their activities" or "tell me about the animals in the picture." Based on their responses, the tester also encouraged the students to participate in further conversation using questions such as, "what activities do you and your family like to do together?" or "what is your favorite animal?" Answers were recorded and carefully analyzed using a rating scale based on a variety of adapted measures.

\section{Reading Task}

At the time of the assessment, the students had just completed a unit on solar energy. In accordance with this familiar theme, students' reading skills were evaluated using a 127-word passage on the topic of solar energy. The passage, written in Spanish, was followed by five corresponding comprehension questions written in English. To avoid any misunderstanding, the students answered the questions in English as well. Each question was worth 1 point, for a combined total of 5 possible points.

\section{Writing Task}

The writing test also included a picture-based activity. The picture depicted a family in a house and emphasized natural resources that they used and wasted. The students were given a word bank of six words and asked to describe the picture in writing. This word bank was used as a springboard for students' completion of the task. Students' writing was evaluated by means of a rubric containing the following categories: mechanics, grammar, semantics, production, and discourse. Each category was worth 3 points, for a combined total of 15 points.

Teachers' Expectations of Students' Performance on the 2003 SFT

Prior to administration of the SFT, the Spanish teachers were asked to rank students as "high," "average," or "low" with respect to their expectations of their students' performances on the SFT. Afterwards, the data from the teachers' expectations for their students' performance were compared with the students' actual performance. This comparison added confidence to the results obtained on the SFT.

\section{Students' Self Reports}

Prior to the SFT, students were asked to fill out a self report about their Spanish learning. The self report included items related to students' oral and literacy skills, their cultural knowledge of Spanish, and their confidence in learning the language.

\section{Teachers' Checklists}

Toward the end of the 2002-2003 school year, sixth grade Spanish teachers were asked to fill out checklists separately designed to elicit their overall impressions of the current Spanish proficiency of both the early learners and the new students, as well as to gather data on student growth. The checklists included the same items that were on the students' self reports. Some examples of these items are, "the majority of students can recombine words to make a short sentence" and "the majority of students can write a paragraph in Spanish that is not a copy of a model provided by the teacher." Data from the teacher's checklists, the students' self reports, and the results of the SFT were all compared.

\section{Results}

Results from the SFT were compared with teachers' expectations of students' performances on the test. In general, the oral and written test results confirmed the expectations of the teachers. Students who were ranked high by the teachers performed well and those who were ranked low performed poorly.

\section{Do Early Learners Outperform New Students on} Their Spanish Oral Skills?

The majority of students from both groups received high scores on the listening task (see Figure 1). However, a careful look at the results on this task reveals a significant difference between the two groups with respect to the number of prompts needed by students to identify the items correctly. Early learners (students 1-27) did not need additional prompts in order to answer correctly. In contrast,
Figure 1

LISTENING COMPREHENSION TASK

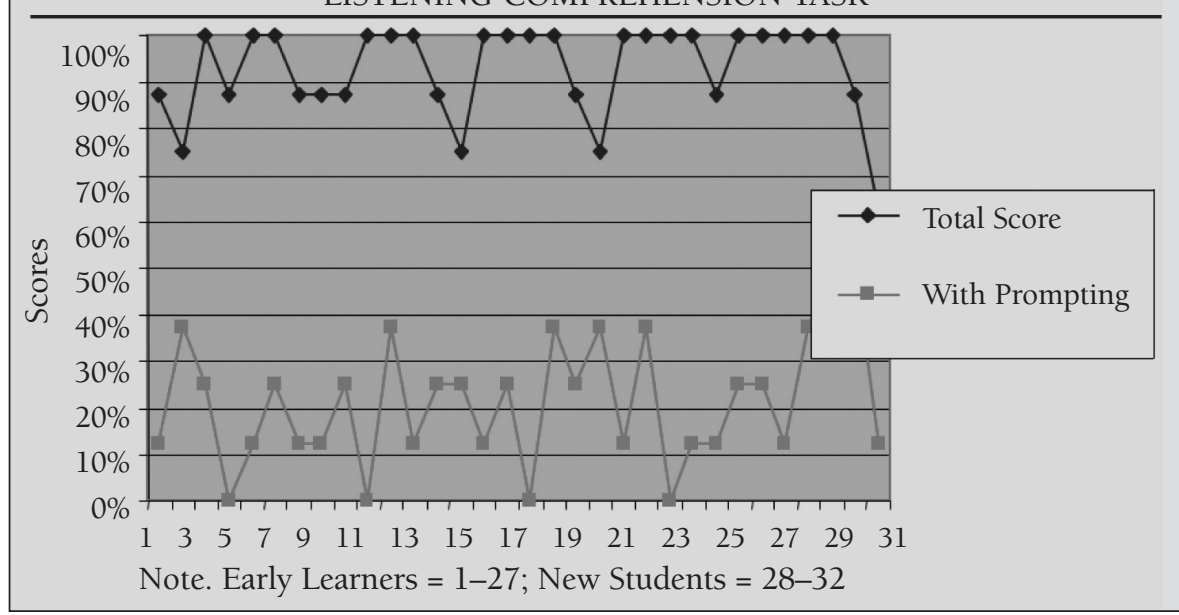


3 new students needed additional prompts in order to respond correctly (students 28-32). The difference of the group means (early learners $=19 \%$; new students $=33 \%$ ) is statistically significant $(t=-2.03)$. Data from the teachers' checklists supported these findings with respect to listening comprehension skills. The Spanish teachers agreed that the early learners comprehend key words and phrases better than the new students. Data from students' self reports also indicated that new students feel less confident of their Spanish comprehension skills than the early learners. These results all support the conclusion that the early learners outperformed the new learners in listening comprehension.

In order to examine the question: Are early learners better than new students in speaking?, results from two tasks were examined. Data from the first oral task reveal no statistically significant difference $(t=-0.09)$ found between the two groups with respect to the number of prompts needed by the students to answer correctly.

Results from the second oral task indicate major differences in students' speaking abilities across groups. Three new students were rated Novice Low, whereas two new students identified as "good students" by their teacher were rated Novice High. For the early learners, only 1 was rated as Novice Low, 9 as Novice Mid, 8 as Novice High, 6 as Intermediate Low, 2 as Intermediate Mid, and 1 as Intermediate High. A closer look at the data from students who were rated as Novice High in both groups reveals that early learners talked more about family members and the likes and dislikes of their family members, whereas new students talked more about academically oriented topics (see Appendix). Data from the teachers' checklists confirm that early learners outperformed new students in their speaking skills in Spanish. Furthermore, the Spanish teachers indicated that the early learners showed more language growth over the school year than the new students. Data collected from students' self-reports also reinforced the teachers' perceptions of the new students' insecurities about their Spanish-speaking skills.

In response to the question: Is the gap between listening and speaking skills greater in the case of new students than in the case of early learners?, data presented here lead to the conclusion that the gap between listening comprehension and speaking skills is greater for new students than for early learners. The early learners outperformed the new learners in their Spanish oral skills. Across groups the majority of students received lower scores in speaking than in listening comprehension.

\section{Are Early Learners More Confident of Their Spanish Oral Skills Than New Students?}

According to the grade 6 Spanish teachers, students who have been learning Spanish since kindergarten are more confident of their Spanish oral proficiency. Results of students' self-reports support teachers' perceptions (see Table 1). Items from the student survey were arranged in six categories: oral comprehension of nonacademic topics, oral comprehension of academic topics, oral production of nonacademic topics, oral production of academic topics, attitudes toward the use of Spanish in the classroom, and attitudes toward the use of Spanish outside the classroom. In all categories, averages from the early learners group were higher than those of new students, leading to the conclusion that the former are more confident in their Spanish oral skills. In addition, the early learners reported a more positive attitude toward speaking Spanish in the classroom than the new students. However, students from both groups reported speaking very little in Spanish to family members and friends outside the classroom.

\section{Do Early Learners Outperform New Students in} Their Spanish Literacy Skills?

Students' results on the reading task range from 20\% for low-ranked students (according to teachers' ranking) to $80 \%$ for highly ranked students. The average for the strong

Table 1

STUDENTS' SELF-REPORTED AVERAGE PROFICIENCY AND ATTITUDES

\begin{tabular}{llcc}
\hline & $\begin{array}{c}\text { Early Learners } \\
(\%)\end{array}$ & $\begin{array}{c}\text { New Students } \\
(\%)\end{array}$ & $t$ \\
\hline Oral comprehension of nonacademic topics & 85 & 40 & $3.5^{*}$ \\
\hline Oral comprehension of academic topics & 98 & 70 & $3.1^{*}$ \\
\hline Oral production of nonacademic topics & 83 & 58 & $3.2^{*}$ \\
\hline Oral production of academic topics & 85 & 80 & 0.4 \\
\hline Attitudes toward the use of Spanish in the classroom & 69 & 40 & $2.5^{*}$ \\
\hline Attitudes toward the use of Spanish outside the classroom & 36 & 20 & 0.9 \\
\hline Total & 66 & 42 & $3.7^{*}$ \\
\hline * Indicates a statistically significant difference between groups. & & & \\
\hline
\end{tabular}


students was $70 \%$ and the average for the low students, including some of the new students, was $48 \%$. The overall average for the early learners was 59\% and the average for the new students was $52 \%$. This difference was not statistically significant. This could be attributed to the fact that some early learners performed lower than the new students. However, the teachers' checklists indicate that they believe that early learners are more confident about their reading skills than new students. Also, the students' selfreports indicate that early learners feel more confident about their reading skills than new learners.

As for their writing skills, early learners outperformed the new students, as seen in Figure 2. The difference of the group means (early learners $=60 \%$; new students $=46 \%$ ) is statistically significant $(t=2.5)$. More specifically, the data show that early learners were able to write more and to use a wider variety of sentence constructions than new students. In addition, there were differences between these two groups in the areas of grammar (word order and agreement) and semantics (vocabulary use and meaning). The teachers' checklists indicate that they believe that both groups can "write a paragraph in Spanish when provided with appropriate support materials," but that only the early learners can "write a paragraph in Spanish that is not a copy of a model provided by the teacher." On the final test, students were not provided with a model and the early learners performed better than the new students, as expected by the teachers. Results from the student self-assessments also confirm that early learners are more confident about their writing skills.

Given the data presented, no conclusive statements can be made with regard to the gap between the reading and writing skills of new students and early learners. While the early learners outperformed the new students in writing, there were no significant differences between these two groups in reading. In addition, even though it might be expected that students would be stronger in reading than in writing, as in the case of their oral skills (listening higher

\section{Figure 2}

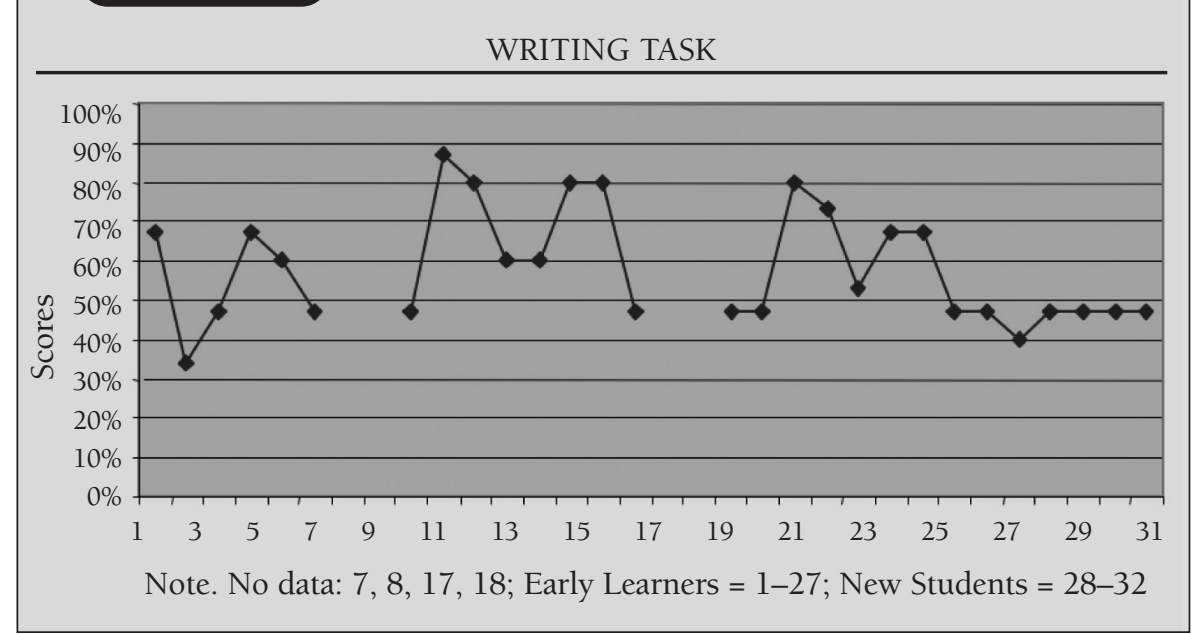

than speaking), the data presented here show that while half of the students did better on the reading test, the other half performed higher on the writing test.

\section{Are Early Learners More Confident About Their} Spanish Literacy Skills Than New Students?

According to the two teachers, students who have been learning Spanish since kindergarten are more confident about their Spanish literacy skills, especially when it comes to producing a text without having a model. Results of students' self-reports (see Table 2) support the teachers' perceptions. Items from the student survey related to writing were divided into writing about academic topics and writing about nonacademic topics. In general, early learners felt more confident about writing both kinds of texts than new students. While early learners felt more confident in writing about nonacademic topics (92\%) than academic topics (74\%), early learners demonstrated the same level of confidence in writing both kinds of texts (50\% for academic and nonacademic texts). Overall, students who have been studying Spanish since kindergarten were more confident about their literacy skills than those who started in grade 6 .

\section{Conclusions}

The limitations of this research are evident. The small sample does not allow us to generalize its results. However, the results from this study correspond to those of Genesee (1987), Harley (1986), Swain and Lapkin (1986), and Wesche, Morrison, Ready, and Pawley (1990). These studies indicated that early learners may have an advantage in oral communication over those who start foreign language instruction later. In addition, an early start may lead students to more confidence in using the target language.

Our study shows that students who started the Spanish program early outperformed new students in their oral skills. The gap between Spanish listening and speaking skills is greater for new students than for early foreign language learners. In addition to feeling more confident with their Spanish oral skills, the early learners reported that they were more inclined to use Spanish for communicating personal feelings than the new students. Results from this study show evidence of the Spanish language growth of early learners, as newer students needed more prompting and more time to respond on some of the tasks of the SFT. In addition, results from the SFT reveal that, even among early learners, there is a wide range of proficiency levels. This reality is a major challenge for foreign language instructors as they attempt to meet the needs of all students at a variety of levels. 
With regard to literacy skills, the results from this study agree with Harley and Wang's findings (1997) in the sense that early learners outperformed newer ones not only in pronunciation, but also in morphology and syntax. The early learners were able to write more and used more sophisticated language structures than the new students. Also, the early foreign language learners felt more confident about writing nonacademic texts than writing academic texts. This may be attributed to the fact that these students had been learning Spanish for 7 years and thus nonacademic topics were more familiar to them. The fact that new students reported the same level of confidence in writing academic and nonacademic texts could be attributed to their recent start in a program that contains a heavy emphasis on literacy.

With respect to reading skills, the results of the reading task indicate that there are no significant differences between the two groups, despite the differences reported by the teachers' checklists and students' self-assessments. The lack of consistency in the results with the writing and reading assessment may be attributable to a number of factors. First, the reading task may not have been a valid and reliable representation of all students' abilities. Second, the new students have three Spanish language support programs that they can take advantage of in this school district: (a) a 2week summer program, (b) a "free-period" remedial program, and (c) the "amigos program," in which high school students tutor new students in the middle school. This support, as well as the organization of the remedial program, may enable new students to approach the same level of proficiency as that of the early foreign language learners in a briefer period of time. Third, the cognitive abilities of the new sixth grade students as well as cross-language transfer of reading skills may allow them to develop proficiency in the language rapidly, especially in reading and writing.

Perhaps the most important factor that may explain the apparent discrepancy in the reading results is the role of "locus of control" (Pierce, Swain, \& Dough, 1999). In a reading task, control is not given to the student: The text is preselected; the level of difficulty is established, and the criteria for comprehension have been previously decided. Conversely, in a writing task, the control of the production resides with the learner. The language selected and used for production is largely controlled by the learners' abilities. As the writing task was open-ended (a picture prompt), the learners had much more control of the task and thus more opportunity to display what they knew rather than what they did not know. In short, there are a number of variables that may explain the inconsistency with the reading skills task results. It is our intention to further explore this matter in future studies, examining the role of locus of control and the impact of instruction on the development of the foreign language learners' literacy.

In summary, the findings of this study shows that beginning foreign language instruction at an early age may be advantageous for developing students' oral skills and their confidence in using the target language. Results also indicate that an early start is beneficial to students' writing development. Despite the small number of participants in the present study, the findings corroborate previous studies that highlight the effectiveness and advantage of early foreign language instruction.

\section{Acknowledgments}

We would like to thank Dick Tucker, Richard Donato, and Heather Hendry for their insightful comments on earlier drafts and Stephanie Maietta for designing the written tests. We also owe a great debt of gratitude to Carol, Joe, Gretchen, Gina, Carole, Natalie, Elizabeth, Melissa and Meghan, who kindly collaborated in gathering the data for this study.

\section{References}

Bennett, S. N. (1975). Weighing the evidence: A review of "Primary French in the balance." British Journal of Educational Psychology, 45, 337-40.

Bongaerts, T., Mennen, S., \& Van der Slik, F. (2000). Authenticity of pronunciation in naturalistic second language acquisition: The case of very advanced late learners of Dutch as a second language. Studia Linguistica, 54, 298-308.

Bongaerts, T., van Summeren, C., Planken, B., \& Schils, E. (1997). Age and ultimate attainment in the pronunciation of a foreign language. Studies in Second Language Acquisition, 19, $447-65$.

Table 2

STUDENTS' SELF-REPORTED AVERAGE LITERACY SKILLS

\begin{tabular}{|c|c|c|c|}
\hline & $\begin{array}{c}\text { Early Learners } \\
(\%)\end{array}$ & $\begin{array}{c}\text { New Students } \\
(\%)\end{array}$ & $t$ \\
\hline Reading comprehension & 82 & 35 & $3.7 *$ \\
\hline Writing of nonacademic texts & 92 & 50 & $4.1^{*}$ \\
\hline Writing of academic texts & 74 & 50 & 1.3 \\
\hline Total & 66 & 42 & $3.7^{*}$ \\
\hline
\end{tabular}


Burstall, C., Jamieson, M., Cohen, S., \& Hargreaves, M. (1974). Primary French in the balance. Windsor: National Foundation for Educational Research.

Cummins, J. (1981). The role of primary language development in promoting educational success for language minority students. In Schooling and language minority students: A theoretical framework (pp. 3-49). Los Angeles: Evaluation, Dissemination and Assessment Center, California State University, Los Angeles.

Cummins, J., \& Swain, M. (1986). Bilingualism in education. New York: Longman.

Curtain, H. A., \& Pesola, C. A. (1994). Language and children-Making the match: Foreign language instruction in the elementary school. Reading, MA: Addison-Wesley.

DeKeyser, R. M. (2000). The robustness of critical period effects in second language acquisition. Studies in Second Language Acquisition, 22, 499-533.

Flege, J. (1999). Age of learning and second language speech. In D. Birdsong (Ed.), Second language acquisition and the critical period hypothesis (pp. 101-131). Mahwah, NJ: Lawrence Erlbaum.

Genesee, F. (1987). Learning through two languages: Studies on immersion and bilingual education. Cambridge, MA: Newbury House.

Harley, B. (1986). Age in second language acquisition. Clevedon, UK: Multilingual Matters.

Harley, B. (1998). The outcomes of early and later language learning. In M. Met (Ed.) Critical issues in early second language learning. Building for our children's future (pp. 26-31). Glenview, IL: Scott Foresman-Addison Wesley.

Harley, B., \& Hart, D. (1997). Language aptitude and second language proficiency in classroom learners of different starting age. Studies in Second Language Acquisition, 19, 379-400.

Harley, B., \& Wang, W. (1997). The critical period hypothesis: Where are we now? In A. M. B. de Groot \& J. F. Kroll (Eds.) Tutorials in bilingualism: Psycholinguistic perspectives. (pp. 26-31). Hillsdale, NJ: Lawrence Erlbaum.

Ioup, G., Boustagui, E., Tigi, M., \& Moselle, M. (1994). Reexamining the critical period hypothesis: A case of successful adult SLA in a naturalistic environment. Studies in Second Language Acquisition, 16, 73-98.

Krashen, S. D., Long, M. A., \& Scarcella, R. C. (1979). Age, rate and eventual attainment in second language acquisition. TESOL Quarterly, 13, 573-82.

Lambert, W., \& MacNamara, J. (1969). Some intellectual consequences of following first-grade curriculum in a foreign language. Journal of Educational Psychology, 60, 69-86.

Lambert, W., \& Tucker G. R. (1972). Bilingual education of children. Rowley, MA: Newbury House.

Lapkin, S., Swain, M., \& Shapson, S. (1990). French immersion research agenda for the '90s. Canadian Modern Language Review, 46, 638-74.

Marinova-Todd, S. H., Marshall, D. B., \& Snow, C. E. (2000). Three misconceptions about age and L2 learning. TESOL Quarterly, 34, 9-34.

Moyer, A. (1999). Ultimate attainment in L2 phonology: The critical factors of age, motivation and instruction. Studies in Second Language Acquisition, 21, 81-108.
National Standards in Foreign Language Education Project (1996). Standards for foreign language learning: Preparing for the 21st century. Yonkers, NY: Author.

Oller, J. W., \& Nagato, N. (1974). The long-term effect of FLES: An experiment. Modern Language Journal, 58, 15-9.

Palmen, M.-J., Bongaerts, T., \& Schils, E. (1997). Lauthenticité de la prononciation dans l'acquisition d'une langage étrangère au-delà de la période critique: Des apprenants néerlandais parvenus à un niveau trés avancé en français. Acquisition et interaction en langage etrangère, 9, 173-91.

Pierce, B., Swain, M., \& Dough, H. (1999). Self-assessment, French immersion, and locus of control. Applied Linguistics, 14(1), 24-41.

Pufahl, I., Rhodes, N., \& Christian, D. (2000). Foreign language teaching: What the United States can learn from other countries. Washington, DC: Center for Applied Linguistics.

Rafferty, E. (1986). Second language study and basic skills in Louisiana. Baton Rouge, LA: Louisiana Department of Education

Scovel, T. (1988). A time to speak: A psycholinguistic inquiry into the critical period for human speech. Rowley, MA: Newbury House.

Singleton, D. (2001). Age and second language acquisition. Annual Review of Applied Linguistics, 21, 77-89.

Stern, H. (1976). Optimal age: Myth or reality? Canadian Modern Language Review, 32, 283-94.

Swain, M. (1984). A review of immersion education in Canada: Research and evaluation studies. In Studies on immersion education: A collection for United States educators (pp. 87-112). Sacramento: California State Department of Education.

Swain, M., \& Lapkin, S. (1986). Immersion French in secondary schools: The "goods" and the "bads." Contact, 5, 2-9.

Tucker, G. R., Donato, R., \& Murday, K. (2001). The genesis of a district-wide Spanish FLES program. In R. L. Cooper, E. Shohamy \& J. Walters (Eds.), New perspectives and issues in educational language policy. In honour of Bernard Dov Spolsky (pp. 235-259). Amsterdam/Philadelphia: John Benjamins.

Wesche, M. B., Morrison, F., Ready D., \& Pawley, C. (1990). French immersion: Post-secondary consequences for individuals and universities. Canadian Modern Language Review, 46, 430-51. 


\section{Appendix}

\section{Second Oral Task Protocol}

T: Tell me everything you can about this picture.

ELL1: Cinco personas en el dibujo/ dos chicos en el dibujo y tres chicas en el dibujo/ una televisión en el dibujo/ uno un computadora en el dibujo/ tres dormitorios en el dibujo [five people in the picture/ two boys in the picture and three girls in the picture/ one TV in the picture/ one computer in the picture/ three bedrooms in the picture]

T: ¿Qué hacen las personas? [What are the people doing?]

ELL1: El chica hablar por teléfono/ un chica leer/ ocho dibujos en el dibujo [the girl talk on the phone/ one girl read/ eight pictures in the picture]

ELL1: Mucho libros ... [much books]

T: ¿Qué colores hay? [What are the colors?]

ELL1: Cafél azul/ montañas [brown, blue, mountains]

T: ¿Cuántas personas hay en tu familia? [How many people are in your family?]

ELL1: Cinco personas en mi familia/ tres chicas en mi familia/ no animales [five people in my family/ three girls in my family/ no animals]

T: ¿Tienes preguntas para mí?[Do you have any questions for me?]

ELL1: ¿Cuántas personas en tu familia? ¿Cuánto chicos en tu familia? ¿Cuánto chicas en tu familia? ¿Cuánto animales en tu familia? [How many people in your family? How much boys in your family? How much girls in your family? How much animals in your family?]

T: Let's look at this picture. Please tell me anything you want about this picture.

ELL1: La energía solar o energía carbón es peor que el energía eólica porque no renovable/ hace energía solar/ energía petróleo es mejor que energía solar porque es no renovable [solar energy or coal energy is worse than the energy from the wind because not renewable/ there is solar energy/ energy from oil is better than solar energy because is not renewable]

T: ¿La energía solar no es renovable? [Solar energy is not renewable?]

ELL1: Energía solar es renovable. [Solar energy is renewable.]

T: ¿Qué más? [What else?]

ELL1: Energía eólica es renovable. [Energy from the wind is renewable.]

$\mathrm{T}$ : ¿Tienes preguntas para mí? [Do you have any questions for me?]

ELL1: ¿Qué tipo es tu favorito? [What type is your favorite?]

T: Tell me about this picture.

ELL1: Olmecas y romanos usan los el comercio. [Olmecs and Romans use it the exchange.]

T: ¿Algo más? [Anything else?]

ELL1: No.

T: ¡Muy bien! [Very good!]

T: Tell me everything you can about this picture.

N1: La chica usa la computadora/ la chica es leer/ la chica es hablar por teléfono/ la chica es euchar la música [the girl uses the computer/ the girl is read/ the girl is talk on the phone/ the girl is listen to music]

T: Dime sobre tu familia. [Tell me about your family.]

N1: Mi familia practicar deportes. [My family do sports.] 
T: ¿Qué deporte? [What sport?]

N1: El béisbol. [Baseball.]

T: ¿Tienes preguntas para mí? [do you have any questions for me?]

N1: No preguntas. [No questions.]

T: Tell me about this picture.

N1: El petróleo es peor que la energía eólica porque es no renovable/ el petróleo, la energía eólica, y los árboles los árboles porque help us breathe [the oil is worse than energy from the wind because it is not renewable/ the oil, the energy from the wind and the trees the trees because help us breathe]

T: Can you tell me about the Olmecs and the Romans?

$\mathrm{N1}$ : Los romanos fueron los romanos niños fueron a los escuelas/ los olmecas estudiron las estrellas/ los romanos usaron los números romanos/ los romanos usaron la alfabeto romano/ los niños los olmecas niños aprendieron los padres [the Romans went Roman children went to the schools/ the Olmecs studied the stars/ the Romans used Roman numbers/ the Romans used the Roman alphabet/ the children the Olmec children learned the parents]

T: ¿Algo más? [Anything else?]

N1: No.

T: ¡Muy bien! [Very good!]

T: Tell me everything you can about this picture.

N2: La chica es usar el computadora. [the girl is use the computer.]

T: ¿Qué más? [What else?]

N2: el chica es hablar on the telefon. [The girl is talk on the phone.]

T: ¿Y el chico? [And the boy?]

N2: el chico es watching mira la television. [The boy is watching watches TV.]

T: ¿Qué colores hay? [What are the colors?]

N2: verde, azul, gris and el blanco. [green, blue, gray and the white]

T: Dime sobre tu familia. [Tell me about your family]

N2: Mi madre. [my mother.]

T: ¿Algo más? [Anything else?]

N2: No.

T: ¿Tienes preguntas para mí? [Do you have any questions for me?]

N2: No.

T: Tell me everything you can about this picture.

N2: Energía solar es mejor que gas natural porque es renovable/ el petróleo es peor que el eólico porque es no renovable/ los árboles es muy muy grande [solar energy is better than natural gas because it is renewable/ oil is worse than the wind because is not renewable/ the trees is very very big]

T: ¿Son importantes los árboles? [Are trees important?]

N2: Los árboles porque es makes... [the trees because is makes]

T: hacen ... [make]

N2: hacen productos. [make products.] 
T: Can you tell me about the Olmecs and the Romans?

N2: La civilización have el catol la religión, la comida, el comercio y los gobiernos/los olmecas hacen muy dioses/ los romanos gobernant es republico/ los olmecas la comida es la maiz/ los romanos hacen muchos dioses [the civilization have Catholicism the religion, the food, the exchange and the governments/the Olmecs make many gods/the Romans goverment is republic/ the Olmecs food is the corn/the Romans make many gods]

T: ¿Qué más? [what else?]

N2: Los niños romanos go to un casa/ los niños olmecas studies [the Roman children go to one house/ the Olmec children studies]

T: estudiaron ... [studied]

N2: estudiaron un padres. [studied one fathers.]

T: ¿Algo más? [Anything else?]

N2: No.

T: ¡Muy bien! [Very good!]

Note. Underline indicates grammar mistakes or errors in pronunciation that cannot be translated.

$E L L=$ Early language learner; $N=$ New student. 